\title{
A rare presentation of hemophagocytic lymphohistiocytosis in a patient with untreated chronic lymphocytic leukemia: A case report and review of the literature
}

\author{
Adaeze Nwosu-Iheme*, Sassine Ghanem, Arpan Patel, Yi Zhuang, Robert Seifert and Hemant Murthy
}

*Correspondence: adaeze.nwosu-iheme@medicine.ufl.edu

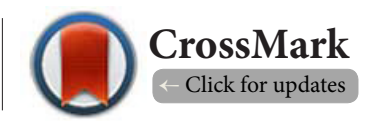

Department of Medicine, University of Florida, Gainesville, FL, USA.

\begin{abstract}
Hemophagocytic Lymphohistiocytosis (HLH) is a state of exaggerated immune response that manifests with multiorgan failure and decreased peripheral counts. Primary HLH is secondary to a genetic defect that leads to a dysregulated immune response and usually manifests in infancy. Secondary HLH is more common in adults and is usually associated with an underlying trigger such as infections (such as Ebstein Bar Virus) or malignancy. HLH has been described with T-cell associated malignancies whereas its association with B-cell malignancies and chronic lymphocytic leukemia (CLL) is rare. We hereby present the case of a patient who presented with HLH secondary to untreated CLL and where no infectious cause was identified. We then review the literature and discuss the diagnosis, prognosis and treatment of HLH most likely triggered by progression of an underlying CLL.
\end{abstract}

Keywords: Hemophagocytic Lymphohistiocytosis, HLH, CLL

\section{Introduction}

Hemophagocytic lymphohistiocytosis $(\mathrm{HLH})$ is a state of uncontrolled cytokine production secondary to an underlying defective natural killer (NK) cell removal of antigen stimulation, resulting in persistent activation and proliferation of cytotoxic T-cell and antigen presenting cells (macrophages, histiocytes). This leads to a state of multisystem inflammation and excessive immune response [1]. The cause of the NK dysfunction and subsequent cytokine storm could be genetic in which case we talk about primary HLH. Secondary HLH is defined as being triggered by an infection, autoimmune diseases, or malignancy. The presence of hemophagocytosis on a bone marrow biopsy while characteristic of the syndrome is nonspecific to $\mathrm{HLH}$. Therefore, the diagnosis relies on clinical suspicion with a set of five out of eight criteria defined by the International Histiocyte Society. The eight diagnostic criteria are: fever, cytopenia of two cell lineage, hypertriglyceridemia and/or hypofibrinogenemia, hyperferritinemia ( $>500 \mathrm{ug} / \mathrm{L}$ ), hemophagocytosis, elevated soluble IL-2 receptor ( $(S C D 25)$, decreased NK cell activity, and splenomegaly [2]. Primary HLH is mainly suspected in the pediatric population as opposed to secondary HLH which is mostly prevalent in adults. The diagnostic evaluation, therefore, will also include exclusion of any underlying conditions (eg, malignant disease) or coexisting infections, establishing the extent of the disease mainly central nervous system involvement, in addition to genetic testing [1]. Among hematological malignancies, the association between HLH and T-cell or NK-cell leukemias and lymphomas, has been well reported whereas the occurrence of HLH in chronic lymphocytic leukemia (CLL) is exceedingly rare [3]. We hereby present the case of a patient who presented with HLH found to be secondary to untreated CLL.

\section{Case presentation}

68-year-old female with a past medical history significant for hormone receptor positive breast cancer treated with lumpectomy and radiation, currently on tamoxifen, presented to an outside hospital with progressive weakness, abdominal pain, bloating and high fevers. Labs revealed profound pancytopenia, abnormal liver function tests with an aspartate aminotransferase (AST) level of $700 \mathrm{IU} / \mathrm{L}$ (normal range 10-40), alanine aminotransferase level (ALT) of $856 \mathrm{IU} / \mathrm{L}$ (normal range 7-56), and an alkaline phosphatase level of $389 \mathrm{IU} / \mathrm{L}$ (normal range 44-147). In addition, she was found to have hyperferritenemia (1800ug/L) and an elevated creatinine level of $4.3 \mathrm{mg} / \mathrm{dL}$ reflecting acute kidney injury as she was normal prior to admission. These lab results were consistent with multi organ failure. 
She was started on empiric broad spectrum antibiotics with vancomycin and piperacillin/tazobactam and transferred to our hospital for further management. The patient reports that one year prior to presentation, she was informed of having an elevated white blood cell (WBC) count concerning for an underlying leukemia but this was never investigated.

On the day of transfer, the patient's blood count revealed a white blood cell (WBC) count of $1.0 \times 10^{9} / \mathrm{L}$, absolute neutrophil count of $0.84 \times 10^{9} / \mathrm{L}$, hemoglobin level of $8.2 \mathrm{~g} / \mathrm{dl}$ and a platelet count of $18 \times 10^{12} / \mathrm{L}$. Other notable lab findings included a ferritin level of $18000 \mu \mathrm{g} / \mathrm{L}$ (normal range 18-360), fibrinogen level of $91 \mathrm{mg} / \mathrm{dL}$ (normal range 150-400), lactate dehydrogenase (LDH) level of $2500 \mathrm{IU} / \mathrm{L}$ (normal range 140 280 ), and a triglyceride level of $340 \mathrm{mg} / \mathrm{dl}$ (normal range 60-149). The extremely elevated ferritin level associated with pancytopenia and multiorgan failure raised the possibility of $\mathrm{HLH}$. We proceeded with a bone marrow biopsy and further diagnostic and etiological workup. The level of soluble CD25 was markedly elevated at $43000 \mathrm{pg} / \mathrm{ml}$ (normal range $<1000 \mathrm{pg} / \mathrm{ml}$ ) with reduced natural killer (NK) cell activity. A computed tomography (CT) scan of the abdomen showed patchy pancolitis with mesenteric lymphadenopathy. An extensive search for an infectious etiology was undertaken but yielded no positive results. This included multiple blood and urine cultures for bacteria, fungi and mycobacteria, PCR tests for EBV , cytomegalovirus, human herpesvirus 6 and 8, Parvovirus, HIV, and the influenza virus as well as serologies for Hepatitis A, B and C. An immunologic screen including antinuclear antibodies, antidouble-stranded DNA antibodies and rheumatoid factor were all negative except for an antismooth muscle antibody level which was positive at 1:160. Bone marrow biospy (BMB) and examination (Figure 1A)

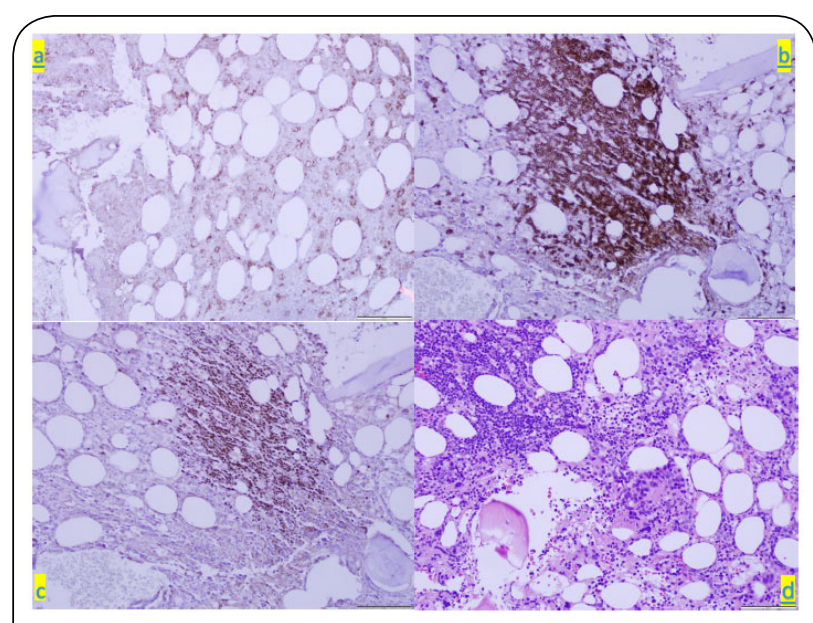

Figure 1. (a,b,c,d) The H\&E demonstrates a hypercellular bone marrow with occasional lymphoid aggregates and increased background histiocytes focally demonstrating hemophagocytosis (d). Furthermore the CD68 stain highlights the histiocytes (a). The lymphoid aggregates are composed primarily of CD5positive (b) and PAX5 positive (c) B cell consistent with CLL involvement (b). showed a hypercellular marrow resulting from an infiltrate of CLL cells coexpressing CD79a, CD20, CD19, CD23, CD5 and PAX5. There was a prominent population of CD68+ macrophages (Fig $1 \mathrm{~b}$ CD68+stain) some of which demonstrated active hemophagocytosis. The bone marrow samples were also stained for viral, fungal and mycobacterial infections and no evidence of infection was found.

The patient did not respond to antibiotic therapy and became increasingly encephalopathic requiring ventilator support for airway protection. Given the fact that we were not able to rule out an infectious process early in the presentation coupled with the fact that her bone marrow results were not confirmed, treatment according to the HLH 2004 protocol (5) was not started. The patient, however, did receive methylprednisolone $2 \mathrm{mg} / \mathrm{kg}$ IV every 24 hours starting 3 days after presentation. The patient's hospital course continued to deteriorate developing worsening coagulopathy, acute kidney injury requiring continuous veno-venous hemofiltration, increasing transaminases, ferritin and LDH levels.

Unfortunately, the patient's family decided to withdraw care and did not want further treatment for either CLL or HLH.

\section{Discussion}

The case of HLH associated B-CLL that was presented fulfills all of the International Histiocyte Society's criteria minus splenomegaly [2]. Of note, 5 out of 8 criteria are needed to diagnosis HLH with high clinical suspicion. Upon presentation, however, the patient did not have any documented history of malignancy. In addition, BMB results require processing and the soluble CD25 levels and NK cell activity are only done at specialized centers therefore all these results are not readily available. The initial assessment could not exclude an infectious origin and therefore antibiotics were initiated in accordance with the surviving sepsis campaign that promotes initiation of broad spectrum antibiotics within the hour in a patient with suspected septic shock [4]. The diagnosis of $\mathrm{HLH}$ was raised due to a lack of response to antibiotics and a deteriorating clinical progression. At the time of establishment of the diagnosis, unfortunately, the family had opted for comfort measures and withdrawal of care. There were several diagnostic challenges that presented with this case.

It has been postulated that the unhindered activation of immune cells in the setting of secondary $\mathrm{HLH}$ results from a combination of an immune response triggered by various stimulants (infectious organisms, tissue damage, metabolic products, etc.) and an underlying immune defect (cytotoxic therapy, transplant, malignancy). The underlying immune defect prevents the culprit antigen from being eliminated and its persistence propagates an excessive immune response with a resultant cytokine storm [5]. The association between $\mathrm{HLH}$ and NK and T-cell related malignancies has been well described in the literature [3]. However, the association between $\mathrm{HLH}$ and B-cell leukemia has been rarely associated (Table 1 ). It is important to note that in the majority of these cases, an 
Table 1. Reported cases of HLH associated with CLL.

\begin{tabular}{|c|c|c|c|c|}
\hline Case & Last Treatment for CLL & Suspected Trigger & $\begin{array}{l}\text { Treatment once diagnosis of HLH } \\
\text { made }\end{array}$ & Outcome \\
\hline $\begin{array}{l}\text { Rao et al } \\
(2002)^{10}\end{array}$ & $\begin{array}{l}\text { Fludarabine and } \\
\text { Cyclophosphamide }\end{array}$ & Histoplasma & $\begin{array}{l}\text { Intravenous amphotericin B then switched } \\
\text { to oral itraconazole } 2 \text { weeks later }\end{array}$ & $\begin{array}{l}\text { Resolution } \\
\text { of HLH }\end{array}$ \\
\hline $\begin{array}{l}\text { Chaker et al } \\
(2010)^{11}\end{array}$ & $\begin{array}{l}\text { Fludarabine and } \\
\text { Cyclophosphamide }\end{array}$ & $\begin{array}{l}\text { EBV infection and Hodgkin's disease } \\
\text { variant of Richter's syndrome after } \\
\text { Fludarabine }\end{array}$ & $\begin{array}{l}\text { Dexamethasone, cyclosporine and } \\
\text { Etoposide (HLH-2004 protocol) }\end{array}$ & Death \\
\hline $\begin{array}{l}\text { Van Koeveringe } \\
\text { and Brouwer } \\
(2010)^{12}\end{array}$ & $\begin{array}{l}\text { Alemtuzumab, Fludarabine and } \\
\text { Cyclophosphamide }\end{array}$ & Histoplasma Capsulatum & $\begin{array}{l}\text { Dexamethasone, cyclosporine and } \\
\text { Etoposide (HLH-2004 protocol) in addition } \\
\text { to caspofungin later switched to } \\
\text { Amphotericin B }\end{array}$ & $\begin{array}{l}\text { Resolution } \\
\text { of HLH }\end{array}$ \\
\hline $\begin{array}{l}\text { Machaczka et } \\
\text { al }(2011)^{5}\end{array}$ & Alemtuzumab & $\begin{array}{l}\text { CLL disease progression, infectious } \\
\text { causes ruled out }\end{array}$ & Etoposide and Corticosteroids & Death \\
\hline $\begin{array}{l}\text { Meki et al } \\
(2011)^{13}\end{array}$ & $\begin{array}{l}\text { Fludarabine and } \\
\text { cyclophosphamide }\end{array}$ & $\begin{array}{l}\text { CLL disease progression, infectious } \\
\text { causes ruled out }\end{array}$ & $\begin{array}{l}\text { Dexamethasone and cyclosporine (HLH- } \\
2004 \text { protocol) followed by Anakinra (IL-1 } \\
\text { receptor antagonist) }\end{array}$ & Death \\
\hline $\begin{array}{l}\text { Lai et al } \\
(2012)^{14}\end{array}$ & $\begin{array}{l}\text { Fludarabine, } \\
\text { Cyclophosphamide and } \\
\text { Rituximab } 5 \text { years prior }\end{array}$ & Influenza A (H1N1) & $\begin{array}{l}\text { HLH was added as a diagnosis at autopsy } \\
\text { so no specific treatment was given prior to } \\
\text { death. }\end{array}$ & Death \\
\hline $\begin{array}{l}\text { Tiong et al } \\
(2012)^{15}\end{array}$ & $\begin{array}{l}\text { Fludarabine, } \\
\text { Cyclophosphamide, and } \\
\text { Rituximab }\end{array}$ & $\begin{array}{l}\text { B-cell suppression by rituximab or T- } \\
\text { cell suppression by fludarabine, } \\
\text { infectious causes ruled out }\end{array}$ & $\begin{array}{l}\text { Dexamethasone, cyclosporine and } \\
\text { Etoposide (HLH-2004 protocol) }\end{array}$ & Death \\
\hline $\begin{array}{l}\text { Kilari et al } \\
(2013)^{16}\end{array}$ & $\begin{array}{l}\text { Pentostatin, cyclophosphamide } \\
\text { and rituximab }\end{array}$ & $\begin{array}{l}\text { CLL disease progression, infectious } \\
\text { causes ruled out }\end{array}$ & $\begin{array}{l}\text { Dexamethasone and cyclosporine (HLH- } \\
2004 \text { protocol) followed by R-CHOP for } \\
\text { CLL. }\end{array}$ & Death \\
\hline \multirow{6}{*}{$\begin{array}{l}\text { Jayakody et al } \\
(2014)^{17} \\
\text { Case series of } 6 \\
\text { patients }\end{array}$} & $\begin{array}{l}\text { Fludarabine and } \\
\text { Cyclophosphamide } 1 \text { month } \\
\text { prior }\end{array}$ & $\begin{array}{l}\text { T cell immunosuppressive effects } \\
\text { secondary to Fludarabine-based } \\
\text { chemotherapy }\end{array}$ & $\begin{array}{l}\text { Dexamethasone, cyclosporine and } \\
\text { Etoposide (HLH-2004 protocol) }\end{array}$ & Death \\
\hline & $\begin{array}{l}\text { Fludarabine and } \\
\text { Cyclophosphamide } 1 \text { month } \\
\text { prior }\end{array}$ & $\begin{array}{l}\text { T cell immunosuppressive effects } \\
\text { secondary to Fludarabine-based } \\
\text { chemotherapy }\end{array}$ & Died prior to treatment & Death \\
\hline & $\begin{array}{l}\text { Fludarabine and } \\
\text { Cyclophosphamide } 7 \text { months } \\
\text { prior }\end{array}$ & $\begin{array}{l}\text { T cell immunosuppressive effects } \\
\text { secondary to Fludarabine-based } \\
\text { chemotherapy }\end{array}$ & $\begin{array}{l}\text { Dexamethasone, cyclosporine and } \\
\text { Etoposide (HLH-2004 protocol) }\end{array}$ & Death \\
\hline & $\begin{array}{l}\text { Fludarabine and } \\
\text { Cyclophosphamide } 24 \text { months } \\
\text { prior }\end{array}$ & $\begin{array}{l}\text { T cell immunosuppressive effects } \\
\text { secondary to Fludarabine-based } \\
\text { chemotherapy }\end{array}$ & $\begin{array}{l}\text { Dexamethasone, cyclosporine and } \\
\text { Etoposide (HLH-2004 protocol) }\end{array}$ & Death \\
\hline & $\begin{array}{l}\text { Fludarabine and } \\
\text { Cyclophosphamide } 22 \text { months } \\
\text { prior and Bendamustine } 1 \\
\text { month prior }\end{array}$ & $\begin{array}{l}\text { T cell immunosuppressive effects } \\
\text { secondary to Fludarabine-based } \\
\text { chemotherapy }\end{array}$ & $\begin{array}{l}\text { Alemtuzumab (Monoclonal antibody } \\
\text { against CD52) }\end{array}$ & Death \\
\hline & $\begin{array}{l}\text { Fludarabine and } \\
\text { Cyclophosphamide } 48 \text { months } \\
\text { prior }\end{array}$ & $\begin{array}{l}\text { T cell immunosuppressive effects } \\
\text { secondary to Fludarabine-based } \\
\text { chemotherapy and } \mathrm{CMV} \text { infection }\end{array}$ & Valganciclovir & $\begin{array}{l}\text { Resolution } \\
\text { of HLH }\end{array}$ \\
\hline $\begin{array}{l}\text { Lim et al } \\
(2014)^{18}\end{array}$ & No prior therapy & EBV & $\begin{array}{l}\text { Antithymocyte globulin, cyclosporine A } \\
\text { and corticosteroids }\end{array}$ & Death \\
\hline $\begin{array}{l}\text { Picque et al } \\
(2014)^{19}\end{array}$ & $\begin{array}{l}\text { Fludarabine, } \\
\text { Cyclophosphamide and } \\
\text { Rituximab } 3 \text { years prior }\end{array}$ & $\begin{array}{l}\text { Early sign for the diagnosis of a } \\
\text { concomitant hepatosplenic T-cell } \\
\text { lymphoma }\end{array}$ & Cyclophosphamide and Etoposide & $\begin{array}{l}\text { Resolution } \\
\text { of HLH }\end{array}$ \\
\hline $\begin{array}{l}\text { Papageorgiou } \\
\text { et al }(2016)^{20}\end{array}$ & $\begin{array}{l}\text { Rituximab for autoimmune } \\
\text { hemolytic anemia secondary to } \\
\text { CLL }\end{array}$ & $\begin{array}{l}\text { EBV reactivation presenting with } \mathrm{HLH} \text {, } \\
\mathrm{HL}-\text {-like Richter's transformation of } \mathrm{B} \text { - } \\
\mathrm{CLL} \text { and bone marrow granulomas }\end{array}$ & $\begin{array}{l}\text { IVIG and corticosteroids initially followed } \\
\text { by an infusion of R-ABVD upon clinical } \\
\text { deterioration }\end{array}$ & Death \\
\hline $\begin{array}{l}\text { Bailey et al } \\
(2017)^{21}\end{array}$ & Untreated & $\begin{array}{l}\text { CLL disease progression, infectious } \\
\text { causes ruled out }\end{array}$ & $\begin{array}{l}\text { Dexamethasone and Etoposide but } \\
\text { without cyclosporine (HLH-2004 protocol) }\end{array}$ & Death \\
\hline $\begin{array}{l}\text { Cavallari et al } \\
(2017)^{22}\end{array}$ & Ibrutinib & $\begin{array}{l}\text { Ibrutinib-induced impairment of NK } \\
\text { degranulation associated with EBV } \\
\text { reactivation and CLL-related } \\
\text { immunodeficiency }\end{array}$ & $\begin{array}{l}\text { Dexamethasone, cyclosporine and IVIG } \\
\text { followed } 30 \text { days later by Tocilizumab (IL-6 } \\
\text { receptor antagonist) }\end{array}$ & Death \\
\hline $\begin{array}{l}\text { Poole et al } \\
(2017)^{9}\end{array}$ & Ibrutinib & Ibrutinib initiation & High dose steroids & Death \\
\hline
\end{tabular}

CLL: Chronic Lymphocytic Leukemia; EBV: Epstein-Barr Virus; HL: Hodgkin’s Lymphoma;

HLH: Hemophagocytic Lymphohistiocytosis; IL: Interleukin; IVIG: Intravenous Immunoglobulins; R-ABVD Rituximab-Doxorubicn, Bleomycin, Vinblastine and Dacarbazine; R-CHOP: Rituximab - Cyclophosphamide, Doxorubicin, Vincristine, and Prednisone 
infectious trigger was detected [10-12,14,17,18,20-22]. It can be therefore postulated that in the setting of a dysfunctional immune system secondary to malignancy, infections are more likely to become overwhelming and act as a trigger for HLH. While an unidentified infectious cause is still a possibility in the remainder of the cases, one must also consider the possibility of noninfectious causes.

Recent observations have disclosed the possibility of gene mutations (e.g. PFR1, STXBP2) influencing late-onset $\mathrm{HLH}$ [5]. Therefore, the possibility of a familial HLH should not be systematically ruled out in case of adult onset $\mathrm{HLH}$. Immunosuppressive therapy has also been implicated as suspected triggers in the case of $\mathrm{HLH}$ associated with CLL. A special interest has been attributed to Fludarabine therapy $[13,15,17]$ as well as ibrutinib $[\mathbf{9 , 2 2}]$. Fludarabine has a profound $T$ cell immunosuppressive effect that is also persistent and has been shown to last for up to two years [17]. A viral infection therefore, if unopposed will be more likely to induce HLH. Ibrutinib was implicated in two cases of CLL associated HLH. Ibrutinib is an irreversible inihibitor of Bruton's Tyrosine Kinase (BTK) and is extremely selective towards BTK. However, it also inhibits several other kinases with a variable affinity. Ibrutinib inhibits IL-2 inducible T-cell kinase (ITK) which is an essential mediator of T-cell differentiation. The inhibition of ITK also affects both NK cell number and degranulation, a functional defect which that is crucial in the pathogenesis of HLH. In addition, ITK deficient patients are prone to EBV lymphoproliferation, a known trigger for HLH6. In the case of untreated CLL where an infectious cause was ruled out, the progression of CLL itself should be implicated as the trigger for HLH. To our knowledge, there has been only four cases reported to date of $\mathrm{HLH}$ secondary to CLL progression in addition to our case $[5,13,16,21]$.

It has been observed that $\mathrm{HLH}$ secondary to malignancy has a worse outcome than infection related HLH. Five-year overall survival has been reported to be lowest in T/NKcell lymphoma-associated HLH (12\%), moderate in B-Cell lymphoma associated $\mathrm{HLH}(48 \%)$, and highest in infection-associated or autoimmune-associated HLH (83-90\%) [7]. The reported cases of $\mathrm{HLH}$ associated with CLL are consistent with this poor prognosis with a $20 \%$ survival $(n=20)$ (Table 1 ). It is important to note that in three out of these four cases, an infectious etiology was diagnosed and treated appropriately $[8,10,15]$. In case of an identified trigger for the immune dysregulation such as infection, treatment for HLH begins with ablation of this trigger. In the absence of an identified trigger then the gold standard remains immunosuppressive therapy with corticosteroids and etoposide based on the HLH-94 protocole1. The study on the HLH-2004 updated protocol is currently underway [2]. Patients with relapsed HLH or those harboring germline mutations in genes associated with $\mathrm{HLH}$ such as PRF1, UNC13D, Munc18-2, Rab27a, STX11, SH2D1A, or BIRC4, should be considered for allogeneic stem cell transplantation with reduced intensity conditioning [8].
Several trials are currently underway investigating novel therapeutic strategies in treating HLH such as tocilizumab, a humanized monoclonal antibody to the IL- 6 receptor and $\mathrm{NI}-0501$, an anti-interferon gamma monoclonal antibody [9].

There are no specific treatment recommendations for $\mathrm{HLH}$ associated with malignancy in the absence of an infectious etiology [5]. The mainstay of treatment should therefore remain as the HLH-2004 protocol in cases of malignancy associated $\mathrm{HLH}$ in the absence of an identified infectious etiology until a more effective therapy is available. In case of a favorable outcome, treatment directed at the malignancy should be pursued in order to prevent the immune system from being suppressed and therefore indirectly preventing the recurrence of HLH. Drugs that might have been implicated such as Ibrutinib or Fludarabine should be avoided if possible.

\section{Conclusion}

Hemophagocytic lymphohistiocytosis is a dysregulated immune response characterized by multiorgan failure with peripheral cytopenias. Secondary HLH is usually associated with infection, malignancy or rarely drug induced. Treatment is directed at eliminating the trigger if identified and suppressing the immune response. In the setting of a patient with a known history of CLL who presents with unremitting fever, the treating physician should have a high clinical suspicion for HLH in view of the associated immune suppression associated with the disease.

\section{Competing interests}

The authors declare that they have no competing interests.

Authors' contributions

\begin{tabular}{|l|c|c|c|c|c|c|}
\hline Authors' contributions & ANI & SG & HM & YZ & SR & AP \\
\hline Research concept and design & $\checkmark$ & -- & -- & -- & -- & -- \\
\hline Collection and/or assembly of data & $\checkmark$ & -- & -- & $\checkmark$ & $\checkmark$ & -- \\
\hline Data analysis and interpretation & -- & -- & -- & -- & -- & -- \\
\hline Writing the article & $\checkmark$ & $\checkmark$ & -- & -- & -- & $\checkmark$ \\
\hline Critical revision of the article & $\checkmark$ & $\checkmark$ & -- & -- & -- & $\checkmark$ \\
\hline Final approval of article & $\checkmark$ & $\checkmark$ & $\checkmark$ & $\checkmark$ & $\checkmark$ & $\checkmark$ \\
\hline Statistical analysis & -- & -- & -- & -- & -- & -- \\
\hline
\end{tabular}

\section{Acknowledgements}

The authors are grateful to nursing staff (who took care of patient) and pathology department at the University of Florida, Gainesville. We are also grateful to our colleagues in hematology who continue to work hard to advance the field of hematology.

Publication history

Editor: Teruya-Feldstein, Memorial Sloan-Kettering Cancer Center, USA.

Received: 15-Nov-2017 Final Revised: 16-Dec-2017

Accepted: 24-Dec-2017 Published: 13-Jan-2018

\section{References}

1. Filipovich $\mathrm{AH}$. Hemophagocytic lymphohistiocytosis (HLH) and related disorders. Hematology Am Soc Hematol Educ Program. 2009; 127-31. | Article I PubMed 
2. Henter JI, Horne A, Arico M, Egeler RM, Filipovich AH, Imashuku S, Ladisch S, McClain K, Webb D, Winiarski J and Janka G. HLH2004: Diagnostic and therapeutic guidelines for hemophagocytic Iymphohistiocytosis. Pediatr Blood Cancer. 2007; 48:124-31. | Article | PubMed

3. Han AR, Lee HR, Park BB, Hwang IG, Park S, Lee SC, Kim K, Lim HY, Ko YH, Kim SH and Kim WS. Lymphoma-associated hemophagocytic syndrome: clinical features and treatment outcome. Ann Hematol. 2007; 86:493-8. | Article | PubMed

4. Rhodes A, Evans LE, Alhazzani W, Levy MM, Antonelli M, Ferrer R, Kumar A, Sevransky JE, Sprung CL, Nunnally ME, Rochwerg B, Rubenfeld GD et al. Surviving Sepsis Campaign: International Guidelines for Management of Sepsis and Septic Shock: 2016. Intensive Care Med. 2017; 43:304-377. I Article I PubMed

5. Machaczka M, Vaktnas J, Klimkowska M and Hagglund H. Malignancyassociated hemophagocytic lymphohistiocytosis in adults: a retrospective population-based analysis from a single center. Leuk Lymphoma. 2011; 52:613-9. I Article I PubMed

6. Ghosh S, Bienemann K, Boztug K and Borkhardt A. Interleukin-2inducible T-cell kinase (ITK) deficiency - clinical and molecular aspects. J Clin Immunol. 2014; 34:892-9. | Article | PubMed Abstract | PubMed FullText

7. Ishii E, Ohga S, Imashuku S, Yasukawa M, Tsuda H, Miura I, Yamamoto K, Horiuchi H, Takada K, Ohshima K, Nakamura S, Kinukawa N, Oshimi K and Kawa K. Nationwide survey of hemophagocytic lymphohistiocytosis in Japan. Int J Hematol. 2007; 86:58-65. | Article | PubMed

8. Marsh RA, Vaughn G, Kim MO, Li D, Jodele S, Joshi S, Mehta PA, Davies SM, Jordan MB, Bleesing JJ and Filipovich AH. Reducedintensity conditioning significantly improves survival of patients with hemophagocytic lymphohistiocytosis undergoing allogeneic hematopoietic cell transplantation. Blood. 2010; 116:5824-31. | Article I PubMed

9. Poole A, Girard N, Clayton F and Tantravahi SK. Rapid onset of hemophagocytic lymphohistiocytosis in a patient with refractory chronic lymphocytic leukemia treated with ibrutinib. Leuk Lymphoma. 2017; 58:1258-1261. | Article | PubMed

10. Rao RD, Morice WG and Phyliky RL. Hemophagocytosis in a patient with chronic lymphocytic leukemia and histoplasmosis. Mayo Clin Proc. 2002; 77:287-90. | Article | PubMed

11. Chaker L, Segeren CM, Bot FJ and Maartense E. Haemophagocytic syndrome and Hodgkin's disease variant of Richter's syndrome after fludarabine for CLL. Eur J Haematol. 2010; 85:91-2. | Article | PubMed

12. van Koeveringe MP and Brouwer RE. Histoplasma capsulatum reactivation with haemophagocytic syndrome in a patient with chronic Iymphocytic leukaemia. Neth J Med. 2010; 68:418-21. | Article | PubMed

13. Meki A, O'Connor D, Roberts C and Murray J. Hemophagocytic lymphohistiocytosis in chronic lymphocytic leukemia. J Clin Oncol. 2011; 29:e685-7. I Article I PubMed

14. Lai S, Merritt BY, Chen L, Zhou X and Green LK. Hemophagocytic lymphohistiocytosis associated with influenza A (H1N1) infection in a patient with chronic lymphocytic leukemia: an autopsy case report and review of the literature. Ann Diagn Pathol. 2012; 16:477-84. | Article | PubMed

15. Tiong IS, Lau MB, Toumoua S and Chiruka S. A case of hemophagocytic lymphohistiocytosis in a patient with chronic lymphocytic leukemia after treatment with fludarabine, cyclophosphamide, and rituximab chemotherapy, with autopsy findings. Case Rep Hematol. 2012 2012:326053. | Article | PubMed Abstract | PubMed FullText

16. Kilari D, Venci N, Friedberg J and Bennett JM. Hemophagocytic lymphohistiocytosis masquerading as progressive chronic lymphocytic leukemia. Leuk Res Rep. 2013; 2:4-6. I Article | PubMed Abstract | PubMed FullText

17. Jayakody Arachchillage D, Hurst E, Carey P, Moses S, O'Brien SG, Menne T, Keenan $\mathrm{F}$ and Wallis JP. Haemophagocytic lymphohistiocytosis following fludarabine/cyclophosphamide chemotherapy for chronic lymphocytic leukaemia. Br J Haematol. 2014; 166:142-5. | Article | PubMed
18. Lim MY, Fedoriw Y, Ramanayake H, Zeitler K, Bardy L and Moll S. EpsteinBarr virus reactivation and hemophagocytic lymphohistiocytosis in a patient with chronic lymphocytic leukemia. Leuk Lymphoma. 2014; 55:2938-41. | Article | PubMed

19. Picque M, Khoury E, Lenoble $M$ and Chait Y. Syndrome d'activation macrophagique révélateur d'un lymphome T hépatosplénique chez une patiente atteinte de leucémie lymphoïde chronique. Ann Biol Clin (Paris). 2014; 72:241-244. I Article

20. Papageorgiou SG, Tsiodras S, Siakallis G, Bazani E, Spathis A, Poulakou G, Korkolopoulou P, Panayiotides I and Pappa V. Epstein barr virus hemophagocytic lymphohistiocytosis related to rituximab use and immunopathogenetic insights. Pathol Res Pract. 2016; 212:1194-1198. I Article I PubMed

21. Bailey C, Dearden C and Ardeshna K. Haemophagocytic lymphohistiocytosis as a consequence of untreated B-cell chronic lymphocytic leukaemia. BMJ Case Rep. 2017; 2017. I Article I PubMed

22. Cavallari M, Ciccone M, Falzoni S, Cavazzini F, Formigaro L, Di Virgilio F, Rotola A, Rigolin GM and Cuneo A. "Hemophagocytic Lymphohistiocytosis after EBV reactivation and ibrutinib treatment in relapsed/refractory Chronic Lymphocytic Leukemia". Leuk Res Rep. 2017; 7:11-13. | Article | PubMed Abstract | PubMed FullText

\section{Citation:}

Nwosu-Iheme A, Ghanem S, Patel A, Zhuang Y, Seifert R and Murthy $\mathrm{H}$. A rare presentation of hemophagocytic lymphohistiocytosis in a patient with untreated chronic lymphocytic leukemia: A case report and review of the literature. Hematol Leuk. 2018; 6:2. http://dx.doi.org/10.7243/2052-434X-6-2 